\title{
The checkpointkinase 2 (CHK2) 1100delC germ line mutation is not associated with the development of squamous cell carcinoma of the head and neck (SCCHN)
}

\author{
Kathrin Scheckenbach ${ }^{1 *}$, Galatia Papadopoulou' ${ }^{1}$, Thomas K Hoffmann ${ }^{1}$, Adam Chaker ${ }^{1}$, Henning Bier ${ }^{2}$,
} Jörg Schipper ${ }^{1}$, Vera Balz', Martin Wagenmann ${ }^{1}$

\begin{abstract}
Background: The checkpointkinase 2 (CHK2) is part of the highly conserved ATM-CHK2 signaling pathway, which is activated in response to DNA damage, in particular after double strand breaks which can be caused by carcinogens like smoking. After induction of downstream targets, e.g. the tumor suppressor p53, its activation leads to cell cycle arrest and apoptosis. Recently, the presence of CHK2 germ line mutations, primarily the 1100delC variant, has been reported to be involved in carcinogenesis. The CHK2 1100delC variant results in a truncated protein which is instable and inactive. Carriers of this variant have been shown to have an increased risk to develop breast cancer and probably also other tumors. Our purpose was to investigate the role of CHK2 germ line mutations in patients with squamous cell carcinoma of the head and neck (SCCHN).
\end{abstract}

Materials and Methods: We investigated 91 patients suffering from SCCHN including all tumor sites (oropharynx, hypopharynx, larynx) for the presence of the germ line mutation 1100delC by direct sequence analysis. Patients were characterized by their tumor localization, tumor stage, age, the presence of additional malignant tumors and predisposing carcinogens (smoking, alcohol abuse).

Results: None of the patients, independently of the tumor site, age, the abuse of predisposing carcinogens, or the presence of other kinds of tumors, carried the CHK2 1100delC variant.

Conclusions: The germ line CHK2 1100delC variant does not seem to have a major impact on the development of SCCHN.

\section{Background}

Head and neck cancer is the fifth most common cancer in the world [1]. The tumor suppressor p53 is strongly involved in the carcinogenesis of these tumors and inactivated either by mutations or human papilloma virus (HPV) infection in most of the cases [2]. Furthermore, squamous cell carcinomas of the head and neck $(\mathrm{SCCHN})$ are associated with smoking and alcohol consumption as risk factors for their development [3]. These genotoxic substances lead to DNA damage; in

\footnotetext{
* Correspondence: scheckenbach@med.uni-duesseldorf.de 'Department of Otorhinolaryngology, Head and Neck Surgery, HeinrichHeine-University Düsseldorf, Germany

Full list of author information is available at the end of the article
}

particular DNA double strand breaks that are removed by different DNA repair mechanisms in healthy cells [4]. Two main checkpoint pathways are initiated in response to DNA damage and lead to either apoptosis or cell cycle arrest to allow chromatin repair: the ATR (ataxia telangiectasia and Rad3 related)-CHK1 (checkpoint kinase 1) -pathway and the ATM-CHK2-pathway. The checkpoint kinase 2 (CHK2, CHEK2) acts as a signal transducer within the highly conserved ataxia telangiectasia-mutated (ATM) protein kinase - CHK2-signaling pathway.

[5-10] Germ line mutations of p53 are normally the hallmark of patients with Li-Fraumeni syndrome, who typically develop tumors at an early age of life at

\section{Biomed Central}


different sites. In 1999, Bell et al. described CHK2 germ line mutations in patients suffering from Li-Fraumeni syndrome or Li-Fraumeni-like syndrome [11] without a germ line p53 mutation. One of the most important mutations was the 1100delC deletion. This variant leads to a frame shift and encodes a premature stop codon within the catalytic domain. The resulting truncated protein is inactive and unstable [12]. The frequency of the 1100delC variant differs within various populations [5]. It was found in $0.9 \%$ of the Northrhine-Westphalia population [13].

The CHK2 1100delC variant has been associated with breast cancer in multiple-case families and has been linked to an approximately 2 -fold increased breast cancer risk. Thus, CHK2 is considered as a "low penetrance gene" for breast cancer [14-18]. CHK2 mutations including the 1100delC variant have also been associated to an elevated risk for prostate [19-22] and bladder cancer [23]. A correlation between CHK2 mutations and colorectal cancer $[20,24,25]$, thyroid cancer and kidney cancer is discussed [20]. CHK2 variants have also been found in other tumors of the lung, larynx, pancreas, stomach as well as melanoma [26], osteosarcoma [27], Non-Hodgkin lymphoma [28], myelodysplastic syndrome or acute myeloid leukemia [29]. However, no definite relation to increased cancer susceptibility was shown [20].

SCCHN are generally carcinogen-induced tumors that show a high rate of p53 inactivation. Therefore, we investigated the presence of the CHK2 1100delC germ line mutation as a potential predisposition for the development of SCCHN with special attention to multitumor patients, and patients who are at low risk for $\mathrm{SCCHN}$ with regard to age or carcinogen abuse.

\section{Methods and Patients \\ Patients}

The study consists of 91 consecutive patients with histologically confirmed SCCHN, including all sites (57 oropharynx, 12 hypopharynx, 22 larynx) and stages $\left(\mathrm{T}_{1-4}\right.$, $\mathrm{N}_{0-3}, \mathrm{M}_{0 / 1}$ ) of disease. After obtaining informed consent, blood samples were taken from each patient. Research was carried out in compliance with the Helsinki Declaration. This study was reviewed and approved by the ethics committee of the University of Düsseldorf.

\section{Sequencing of the CHK2 exon 10 including the 1100 delC variant}

DNA was isolated from peripheral blood lymphocytes (Genomic DNA purification kit, Genera Biosystems, Minneapolis, USA). Exon 10 of the CHK2 gene was amplified in a standard PCR reaction using Qiagen Mastermix (Qiagen, Hilden, Germany) and primers (5'-GCA AAA TTA AAT GTC CTA ACT TGC-3', 5'-TCT GCC CAG ACT TCA GGA AT-3'). PCR amplification was performed as a "touch down PCR". It comprised 35 cycles subdivided into 3 cycles of denaturing for $15 \mathrm{sec}$ at $94^{\circ} \mathrm{C}$, annealing for $15 \mathrm{sec}$ at $68^{\circ} \mathrm{C}$, and extension for $45 \mathrm{sec}$ at $72^{\circ} \mathrm{C}$ followed by 3 cycles of denaturing for 15 sec at $94^{\circ} \mathrm{C}$, annealing for $15 \mathrm{sec}$ at $63^{\circ} \mathrm{C}$, and extension for $45 \mathrm{sec}$ at $72^{\circ} \mathrm{C}$ followed by 3 cycles of denaturing for $15 \mathrm{sec}$ at $94^{\circ} \mathrm{C}$, annealing for $15 \mathrm{sec}$ at $58^{\circ} \mathrm{C}$, and extension for $45 \mathrm{sec}$ at $72^{\circ} \mathrm{C}$. The PCR was preceded by 3 min at $94^{\circ} \mathrm{C}$ and followed by $7 \mathrm{~min}$ at $72^{\circ} \mathrm{C}$. The amplificates were purified (Qiaquick, Qiagen), and mixed with ABI PRISM BigDye Terminator sequencing kit (Applied Biosystems, Weiterstadt, Germany) and primers (5'CCA GAT TAA TGG CAG GTG TG-3' for sense direction or 5'CCT ACC AGT CTG TGC AGC AA-3'for antisense direction). After the sequencing reaction (25 cycles of $15 \mathrm{sec}$ at $96^{\circ} \mathrm{C}$ and $4 \mathrm{~min}$ at $60^{\circ} \mathrm{C}$ ), the products were gel-purified (DyeEx 2.0 Spin Kit, Qiagen) and analyzed with an automated sequencer (ABI 310, Applied Biosystems). A sample representing the wild type sequence of CHK2 Exon 10 served as control. All samples underwent confirmation by repeated analysis.

\section{Results}

The 91 investigated patients with histologically confirmed squamous cell carcinoma of the head and neck (SCCHN) comprised 15 women and 76 men. Their age ranged from 32 to 82 years with a mean of 56 years. A relatively high proportion (12 patients) were aged under 40 years at the time of diagnosis and can thus be considered as young for the development of a SCCHN. The majority (57) suffered from oropharyngeal carcinoma, 12 showed hypopharyngeal carcinoma, and 22 had laryngeal carcinoma (Table 1).

In 49 patients, cervical lymph node metastases were found while 42 patients showed no metastases. Distant metastases were determined in 3 patients. 21 patients also suffered from other malignant or semi-malignant tumors (Table 2). Some patients had tumors at multiple sites. One patient had a history of an esophagus carcinoma, a basal cell carcinoma, and a melanoma; another one suffered from a prostate and a bladder carcinoma, and one patient experienced a colon carcinoma and a basal cell carcinoma.

\begin{tabular}{|c|c|c|c|}
\hline Tumor Stage & $\begin{array}{l}\text { Oropharynx } \\
n=57\end{array}$ & $\begin{array}{l}\text { Hypopharynx } \\
\mathrm{n}=12\end{array}$ & $\begin{array}{l}\text { Larynx } \\
\mathrm{n}=22\end{array}$ \\
\hline $\mathrm{T1}$ & 16 & 1 & 10 \\
\hline $\mathrm{T} 2$ & 21 & 8 & 6 \\
\hline T3 & 15 & 1 & 3 \\
\hline T4 & 5 & 2 & 3 \\
\hline
\end{tabular}


Table 2 The table shows number of patients suffering from second malignancy.

\begin{tabular}{ll}
\hline Secondary malignancy & $\begin{array}{l}\text { Number of Patients suffering from a } \\
\text { secondary malignancy }\end{array}$ \\
\hline Esophagus & 6 \\
Lung & 3 \\
Basal Cell Carcinoma & 4 \\
Bladder & 3 \\
Prostate & 3 \\
Colon & 2 \\
Chronic myeloid & 1 \\
leukemia (CML) & \\
Chronic lymphocytic & 1 \\
leukemia (CLL) & \\
Melanoma & 1 \\
\hline
\end{tabular}

16 of the patients were non-smokers with a high proportion of $75 \%$ (12 out of 16 ) of patients showing an oropharyngeal cancer.

14 of those also were no habitual drinkers. Altogether, 23 patients reported moderate to seldom alcohol consumption (less than once a week). The remaining patients were mostly heavy smokers and drinkers.

Sequence analysis of exon 10 of the CHK2 gene was performed for all patients. However, none of the patients showed the presence of the $1100 \mathrm{delC}$ variant.

\section{Discussion}

None of the investigated 91 patients with SCCHN carried the CHK2 1100delC variant. The incidence of 1100 delC in the population of the state NorthrhineWestphalia in Germany is reported to be $0.9 \%$. Because our investigation took place exactly in this region, we accepted the published data as a control group for our patients [13]. Hence, we did not determine any significant difference in the incidence of the CHK2 1100delC variant between the tumor group $(0 \%)$ and the control group $(0.9 \%)$. Compared to the study sizes of some other investigators, we only investigated a relatively small group of 91 patients. But if the CHK2 1100delC variant had a major impact for the development of SCCHN, at least some of the patients should have been positive for this mutation.

The heterozygous germ line mutation 1100delC of CHK2 was previously reported to be associated to breast cancer [18], bladder cancer [23] and prostate cancer [19-22] and perhaps also to other carcinomas [20,24,25]. Cybulski et al. analyzed multiple kinds of carcinomas for CHK2 germ line mutations. This study also included 245 laryngeal carcinomas [20]. In this group of patients, they did not detect any truncating mutation. Therefore, we were able to confirm these results. Nevertheless, they found the missense I157T mutation in $4.1 \%$ of the cases. In this study, the incidence of this variant within the tumor group did not significantly differ from the control group. Furthermore, Cybulski et al. more recently performed an additional investigation where they analyzed 895 cases of lung cancer, 430 cases of laryngeal cancer and 6391 controls for the I157T variant. They reported that the I157T variant appears to be associated with a decreased risk for developing lung cancer and laryngeal cancer [30]. In this case, CHK2 alterations may be not predisposing but protective for head and neck cancer. In our study, we did not screen our patients for this variant yet.

Until now, no data for two additional major tumor sites in the head and neck area, hypopharynx and oropharynx, were available for the risk of predisposing $\mathrm{CHK} 2$ mutations. In the present study, we did not find the CHK2 1100delC variant in any of these patients.

Moreover, patients suffering from multiple tumor types including squamous cell carcinoma of the head and neck, showed no CHK2 1100delC variant. This indicates that this particular germ line variation plays no significant role for the development of cancer of the upper aerodigestive tract.

However, CHK2 may play a role either in the defense or the carcinogenesis of these tumors. The ATM-driven DNA-damage pathway seems to be activated in due to tobacco smoke, a major carcinogen for the development of SCCHN, as Tanaka et al recently showed [31]. Because CHK2 is a major target of ATM, a smokingdependent-CHK2 activation in SCCHN is likely. Yoon et al. investigated the expression of phosphorylated $\mathrm{CHK} 2$ (pCHK2) and therefore activated CHK2 in precancerous lesions of the oral mucosa immunohistochemically. He found that subjects with a positive pCHK2 staining had a significantly ( 8.6 fold) higher risk to develop a squamous cell carcinoma out of this lesion. He suggested $\mathrm{pCHK} 2$ as a putative biomarker for oral precancerous lesions [32]. However, the authors did not investigate the occurrence of CHK2 mutations. Serbia et al. investigated the pCHK2 status of squamous cell carcinomas of the esophagus in patients who underwent neoadjuvant chemotherapy (RTX) immunohistochemically. They described that $\mathrm{pCHK} 2$ positive tumors more frequently showed clinical regression after RTX [33]. Because esophageal cancer is closely related to the upper aerodigestive tract, a similar behavior might be assumed for SCCHN.

\section{Conclusion}

The typical 1100delC germ line mutation does not seem to have a major impact on the risk to develop squamous cell carcinoma of the head and neck. Since this study is limited by a relatively low case number, additional studies including larger groups of patients should be performed. Furthermore, the detection of $\mathrm{CHK} 2$ variations 
other than 1100delC in SCCHN as well as the definition of the role of $\mathrm{CHK} 2$ in the carcinogenesis of SCCHN remain to be an interesting matter for future investigations.

\section{Abbreviations}

ATM: ataxia telangiectasia-mutated protein kinase; ATR: ataxia telangiectasia and Rad3 related; BRCA1: breast cancer 1; CDC25A: cell division cycle 25 homolog A; CDC25C: cell division cycle 25 homolog C; CHK1: checkpoint kinase 1; CHK2: checkpoint kinase 2; E2F1: E2F transcription factor 1; FHA: forehead-associated domain; HPV: human papilloma virus; PIKK: phosphatidylinositol-3 kinase (PI-3K)-like kinase; PML: promyelocytic leukemia protein; SCCHN: squamous cell carcinomas of the head and neck

\section{Acknowledgements}

We are grateful to the patients who participated in this study. All direct and indirect costs of this study were funded by the University of Düsseldorf.

\section{Author details}

'Department of Otorhinolaryngology, Head and Neck Surgery, HeinrichHeine-University Düsseldorf, Germany. ${ }^{2}$ Department of Otorhinolaryngology, Head and Neck Surgery, Technical University of Munich, Germany.

\section{Authors' contributions}

KS performed most of the sequencing, isolated DNA, organized the study and wrote most parts of the article. GP collected the patient's samples and isolated DNA. MW wrote parts of the article, collected samples and investigated patients. AC and TKH collected samples and investigated patients. HB and JS corrected the article and investigated patients. VB wrote parts of the article, designed the primers and performed sequencing. All authors read and approved the final manuscript.

\section{Competing interests}

The authors declare that they have no competing interests.

Received: 15 June 2010 Accepted: 25 December 2010

Published: 25 December 2010

\section{References}

1. Parking DM, Bray F, Ferlay J, Pisano P: Estimating the world cancer burden: Glob can 2000. Int J Cancer 2001, 94(2):153-6.

2. Balz V, Scheckenbach K, Gotte K, Bockmuhl U, Petersen I, Bier H: Is the p53 inactivation frequency in squamous cell carcinomas of the head and neck underestimated? Analysis of p53 exons 2-11 and human papillomavirus 16/18 E6 transcripts in 123 unselected tumor specimens. Cancer Res 2003, 63(6):1188-91.

3. Dahlstrom KR, Little JA, Zafereo ME, Lung M, Wei Q, Sturgis EM: Squamous cell carcinoma of the head and neck in never smoker-never drinkers: a descriptive epidemiologic study. Head Neck 2008, 30(1):75-84.

4. Danoy P, Michiels S, Dessen P, Pignat C, Boulet T, Monet M, Bouchardy C, Lathrop M, Sarasin A, Benhamou S: Variants in DNA double-strand break repair and DNA damage-response genes and susceptibility to lung and head and neck cancers. Int J Cancer 2008, 123(2):457-63.

5. Nevanlinna $H$, Bartek J: The CHEK2 gene and inherited breast cancer susceptibility. Oncogene 2006, 25(43):5912-9.

6. Pommier $\mathrm{Y}$, Sordet $\mathrm{O}$, Rao VA, Zhang H, Kohn KW: Targeting chk2 kinase: molecular interaction maps and therapeutic rationale. Curr Pharm Des 2005, 11(22):2855-72.

7. Bartek J, Lukas J: Chk1 and Chk2 kinases in checkpoint control and cancer. Cancer Cell 2003, 3(5):421-9.

8. Hirao A, Cheung A, Duncan G, Girard PM, Elia AJ, Wakeham A, Okada H, Sarkissian T, Wong JA, Sakai T, De Stanchina E, Bristow RG, Suda T, Lowe SW, Jeggo PA, Elledge SJ, Mak TW: Chk2 is a tumor suppressor that regulates apoptosis in both an ataxia telangiectasia mutated (ATM)dependent and an ATM-independent manner. Mol Cell Biol 2002, 22(18):6521-32.

9. Takai H, Naka K, Okada Y, Watanabe M, Harada N, Saito S, Anderson CW Appella E, Nakanishi M, Suzuki H, Nagashima K, Sawa H, Ikeda K,
Motoyama N: Chk2-deficient mice exhibit radioresistance and defective p53-mediated transcription. Embo J 2002, 21(19):5195-205.

10. Hirao A, Kong YY, Matsuoka S, Wakeham A, Ruland J, Yoshida H, Liu D, Elledge SJ, Mak TW: DNA damage-induced activation of p53 by the checkpoint kinase Chk2. Science 2000, 287(5459):1824-7.

11. Bell DW, Varley JM, Szydlo TE, Kang DH, Wahrer DC, Shannon KE, Lubratovich M, Verselis SJ, Isselbacher KJ, Fraumeni JF, Birch JM, Li FP, Garber JE, Haber DA: Heterozygous germ line hCHK2 mutations in LiFraumeni syndrome. Science 1999, 286(5449):2528-31.

12. Wu X, Webster SR, Chen J: Characterization of tumor-associated Chk2 mutations. J Biol Chem 2001, 276(4):2971-4.

13. Rashid MU, Jakubowska A, Justenhoven C, Harth V, Pesch B, Baisch C, Pierl CB, Bruning T, Ko Y, Benner A, Wichmann HE, Brauch H, Hamann U: German populations with infrequent CHEK2*1100delC and minor associations with early-onset and familial breast cancer. Eur J Cancer 2005, 41(18):2896-903.

14. Vahteristo P, Bartkova J, Eerola H, Syrjakoski K, Ojala S, Kilpivaara O, Tamminen A, Kononen J, Aittomaki K, Heikkila P, Holli K, Blomqvist C, Bartek J, Kallioniemi OP, Nevanlinna H: A CHEK2 genetic variant contributing to a substantial fraction of familial breast cancer. Am J Hum Genet 2002, 71(2):432-8.

15. Oldenburg RA, Kroeze-Jansema K, Kraan J, Morreau H, Klijn JG, Hoogerbrugge $N$, Ligtenberg MJ, van Asperen CJ, Vasen HF, Meijers C Meijers-Heijboer H, de Bock TH, Cornelisse CJ, Devilee P: The CHEK2*1100delC variant acts as a breast cancer risk modifier in nonBRCA1/BRCA2 multiple-case families. Cancer Res 2003, 63(23):8153-7.

16. Meijers-Heijboer $H$, van den Ouweland A, Klijn J, Wasielewski M, de Snoo A, Oldenburg R, Hollestelle A, Houben M, Crepin E, van Veghel-Plandsoen M, Elstrodt F, van Duijn C, Bartels C, Meijers C, Schutte M, McGuffog L, Thompson D, Easton D, Sodha N, Seal S, Barfoot R, Mangion J, Chang Claude J, Eccles D, Eeles R, Evans DG, Houlston R, Murday V, Narod S, Peretz T, Peto J, Phelan C, Zhang HX, Szabo C, Devilee P, Goldgar D, Futreal PA, Nathanson KL, Weber B, Rahman N, Stratton MR: Lowpenetrance susceptibility to breast cancer due to CHEK2 $\left.{ }^{*}\right) 1100 \mathrm{delC}$ in noncarriers of BRCA1 or BRCA2 mutations. Nat Genet 2002, 31(1):55-9.

17. The CHEK2 Breast Cancer Case-Control Consortium 2004: CHEK2*1100delC and susceptibility to breast cancer: a collaborative analysis involving 10,860 breast cancer cases and 9,065 controls from 10 studies. Am J Hum Genet 2004, 74(6):1175-82.

18. Weischer M, Bojesen SE, Ellervik C, Tybjaerg-Hansen A, Nordestgaard BG CHEK2*1100delC genotyping for clinical assessment of breast cancer risk: meta-analyses of 26,000 patient cases and 27,000 controls. J Clin Oncol 2008, 26(4):542-8.

19. Cybulski C, Huzarski T, Gorski B, Masojc B, Mierzejewski M, Debniak T, Gliniewicz B, Matyjasik J, Zlowocka E, Kurzawski G, Sikorski A, Posmyk M, Szwiec M, Czajka R, Narod SA, Lubinski J: A novel founder CHEK2 mutation is associated with increased prostate cancer risk. Cancer Res 2004, 64(8):2677-9.

20. Cybulski C, Gorski B, Huzarski T, Masojc B, Mierzejewski M, Debniak T, Teodorczyk U, Byrski T, Gronwald J, Matyjasik J, Zlowocka E, Lenner M, Grabowska E, Nej K, Castaneda J, Medrek K, Szymanska A, Szymanska J, Kurzawski G, Suchy J, Oszurek O, Witek A, Narod SA, Lubinski J: CHEK2 is a multiorgan cancer susceptibility gene. Am J Hum Genet 2004, 75(6):1131-5.

21. Dong X, Wang L, Taniguchi K, Wang X, Cunningham JM, McDonnell SK, Qian C, Marks AF, Slager SL, Peterson BJ, Smith DI, Cheville JC, Blute ML, Jacobsen SJ, Schaid DJ, Tindall DJ, Thibodeau SN, Liu W: Mutations in CHEK2 associated with prostate cancer risk. Am J Hum Genet 2003, 72(2):270-80.

22. Seppala EH, Ikonen $T$, Mononen $N$, Autio V, Rokman A, Matikainen MP Tammela TL, Schleutker J: CHEK2 variants associate with hereditary prostate cancer. Br J Cancer 2003, 89(10):1966-70.

23. Zlowocka E, Cybulski C, Gorski B, Debniak T, Slojewski M, Wokolorczyk D, Serrano-Fernandez P, Matyjasik J, van de Wetering T, Sikorski A, Scott RJ, Lubinski J: Germline mutations in the CHEK2 kinase gene are associated with an increased risk of bladder cancer. Int J Cancer 2008, 122(3):583-6.

24. Kilpivaara O, Laiho P, Aaltonen LA, Nevanlinna H: CHEK2 1100delC and colorectal cancer. J Med Genet 2003, 40(10):e110.

25. Lipton L, Fleischmann C, Sieber OM, Thomas HJ, Hodgson SV, Tomlinson IP, Houlston RS: Contribution of the CHEK2 1100delC variant to risk of 
multiple colorectal adenoma and carcinoma. Cancer Lett 2003, 200(2):149-52.

26. Debniak T, Scott RJ, Gorski B, Cybulski C, van de Wetering T, SerranoFernandez P, Huzarski T, Byrski T, Nagay L, Debniak B, Kowalska E,

Jakubowska A, Gronwald J, Wokolorczyk D, Maleszka R, Kladny J, Lubinski J: Common variants of DNA repair genes and malignant melanoma. Eur J Cancer 2008, 44(1):110-4.

27. Miller CW, Ikezoe T, Krug U, Hofmann WK, Tavor S, Vegesna V, Tsukasaki K, Takeuchi S, Koeffler HP: Mutations of the CHK2 gene are found in some osteosarcomas, but are rare in breast, lung, and ovarian tumors. Genes Chromosomes Cancer 2002, 33(1):17-21.

28. Tavor S, Takeuchi S, Tsukasaki K, Miller CW, Hofmann WK, Ikezoe T, Said JW, Koeffler HP: Analysis of the CHK2 gene in lymphoid malignancies. Leuk Lymphoma 2001, 42(3):517-20.

29. Hofmann WK, Miller CW, Tsukasaki K, Tavor S, Ikezoe T, Hoelzer D, Takeuchi S, Koeffler HP: Mutation analysis of the DNA-damage checkpoint gene CHK2 in myelodysplastic syndromes and acute myeloid leukemias. Leuk Res 2001, 25(4):333-8.

30. Cybulski C, Masojc B, Oszutowska D, Jaworowska E, Grodzki T, Waloszczyk P, Serwatowski P, Pankowski J, Huzarski T, Byrski T, Gorski B, Jakubowska A,

Debniak T, Wokolorczyk D, Gronwald J, Tarnowska C, Serrano-Fernandez P, Lubinski J, Narod SA: Constitutional CHEK2 mutations are associated with a decreased risk of lung and laryngeal cancers. Carcinogenesis 2008, 29(4):762-5.

31. Tanaka T, Huang X, Jorgensen E, Gietl D, Traganos F, Darzynkiewicz Z, Albino AP: ATM activation accompanies histone H2AX phosphorylation in A549 cells upon exposure to tobacco smoke. BMC Cell Biol 2007, 8:26.

32. Yoon AJ, Shen J, Santella RM, Zegarelli DJ, Chen R, Weinstein IB: Activated checkpoint kinase 2 expression and risk for oral squamous cell carcinoma. Cancer Epidemiol Biomarkers Prev 2007, 16(12):2768-72.

33. Sarbia M, Ott N, Puhringer-Oppermann F, Brucher BL: The predictive value of molecular markers (p53, EGFR, ATM, CHK2) in multimodally treated squamous cell carcinoma of the oesophagus. Br J Cancer 2007, 97(10):1404-8.

doi:10.1186/1477-5751-9-10

Cite this article as: Scheckenbach et al: The checkpointkinase 2 (CHK2) 1100delC germ line mutation is not associated with the development of squamous cell carcinoma of the head and neck (SCCHN). Journal of Negative Results in BioMedicine 2010 9:10.

\section{Submit your next manuscript to BioMed Central and take full advantage of:}

- Convenient online submission

- Thorough peer review

- No space constraints or color figure charges

- Immediate publication on acceptance

- Inclusion in PubMed, CAS, Scopus and Google Scholar

- Research which is freely available for redistribution

Submit your manuscript at www.biomedcentral.com/submit
Biomed Central 